\title{
Morphological observations on three Baltic species of Corynosoma Lühe, 1905 (Acanthocephala, Polymorphidae)
}

\author{
Sonja LEIDENBERGER ${ }^{1, *}$, Sven BOSTRÖM${ }^{2} \&$ Matthew T. WAYLAND ${ }^{3}$ \\ ${ }^{1}$ Department of Biology and Bioinformatics, University of Skövde, Sweden. \\ ${ }^{2}$ Department of Zoology, Swedish Museum of Natural History, Stockholm, Sweden. \\ ${ }^{3}$ Department of Zoology, University of Cambridge, Cambridge CB2 3EJ, United Kingdom. \\ *Corresponding author: sonja.leidenberger@his.se \\ ${ }^{2}$ Email: sven.bostrom@nrm.se \\ 33Email: mw283@cam.ac.uk \\ ${ }^{1}$ urn:lsid:zoobank.org:author:5DF3F2C0-2A38-4615-8E98-605DD8861A0D \\ ${ }^{2}$ urn:lsid:zoobank.org:author:528300CC-D0F0-4097-9631-6C5F75922799 \\ ${ }^{3}$ urn:1sid:zoobank.org:author:BC4F8861-916C-4E43-86EE-632021D274D1
}

\begin{abstract}
Necropsies of Baltic grey (Halichoerus grypus) and ringed seals (Pusa hispida) presented a rare opportunity to study their acanthocephalan fauna. Both species hosted adults of three species of the genus Corynosoma Lühe, 1904, namely C. magdaleni Montreuil, 1958, C. semerme (Forsell, 1904) Lühe 1911 and C. strumosum (Rudolphi, 1802) Lühe 1904. A comparative morphological analysis of these three species of Corynosoma, combining both light and scanning electron microscopy, was performed for the first time. Sexual dimorphism in the size and shape of the trunk was observed in both C. magdaleni and C. semerme, but there was insufficient material to investigate this phenomenon in C. strumosum. Genital spines were not observed in any of the female acanthocephalans. Three possible explanations for the presence of genital spines in some females, but not others are (i) cryptic speciation, (ii) phenotypic variation and (iii) loss by extraction or shearing when the copulatory cap is released. Copulatory caps were observed on female $C$. semerme. The size and morphology showed considerable variability and all caps were strongly autofluoresecent.
\end{abstract}

Keywords. Baltic Sea, grey seals, ringed seals, SEM, thorny-headed worms.

Leidenberger S., Boström S. \& Wayland M. T. 2019. Morphological observations on three Baltic species of Corynosoma Lühe, 1905 (Acanthocephala, Polymorphidae). European Journal of Taxonomy 514: 1-19. https://doi.org/10.5852/ejt.2019.514

\section{Introduction}

The Baltic Sea area, one of the largest areas of brackish water in the world, is characterised by a strong salinity gradient from marine waters at the Swedish west coast, to brackish water in the Baltic Proper, and nearly freshwater in the Bothnian Bay and Gulf of Finland. In the latter regions, populations of grey seals, Halichoerus grypus (Fabricius, 1791) and ringed seals, Pusa hispida (Schreber, 1775) 
coexist. Baltic seal species are often heavily infested with a variety of metazoan parasites, including the seal louse Echinophthirius horridus (von Olfers, 1816) (Arthropoda: Echinophthiriidae), the heartworm Acanthocheilonema spirocauda (Leidy, 1858) (Nematoda: Onchocercidae), the lungworm Otostrongylus circumlitus (Railliet, 1899) (Nematoda: Crenosomatidae) and thorny-headed worms of the genus Corynosoma Lühe, 1904 (Acanthocephala: Polymorphidae) (see Leidenberger et al. 2007; Leidenberger \& Boström 2008, 2009).

Seals of the Baltic Sea are the definitive host of three species of Corynosoma, namely C. magdaleni Montreuil, 1958, C. semerme (Forssell, 1904) Lühe 1911 and C. strumosum (Rudolphi, 1802) Lühe 1904. The species of Corynosoma in the Baltic Sea are not morphologically well characterized. Most studies of these acanthocephalans addressed ecological questions (e.g., Sinisalo et al. 2003, 2004; Valtonen et al. 2004). Nickol et al. (2002) provided morphological descriptions of $C$. magdaleni and C. strumosum from the Gulf of Bothnia and these included detailed line drawings but no micrographs from light microscopy (LM) or scanning electron microscopy (SEM). Recently, Waindok et al. (2018) used DNA sequence data to characterize species of Corynosoma from harbour seals and grey seals of the German North and Baltic Seas. However, their morphological observations were restricted to a limited number of morphometric and meristic measurements.

In the present study, we used LM and SEM to make observations on the morphology of Corynosoma spp. found in grey and ringed seals in the Baltic Sea coast of Sweden.

\section{Material and methods}

Thorny-headed worms were collected during seal necropsies at the Swedish Museum of Natural History (SMNH) between 2007 and 2008 (Table 1). The seals were caught through hunting in Baltic Sea regions along the coast of Sweden at this time (Leidenberger \& Bäcklin 2008). A total of ten grey seals, $H$. grypus of both genders, and ranging in age 0-21 years (determined by growth layer groups after Hewer 1964), were collected from the following Swedish provinces: Skärplinge and Östhammar/Upplands Province, Hudiksvall and Stocka/Gävleborgs Province, and Luleå/Norrbottens province (Fig. 1). Three ringed seals, $P$. hispida, were collected from Tisteröarna/Norrbottens Province (Table 1, Fig. 1). The seals were frozen after capture for storage, and then thawed prior to necropsy. All seals were infected by Corynosoma spp. (prevalence: $100 \%$ ). One grey seal individual had a mixed infection of all three species, and four individuals had a mixed infection with two species. In ringed seals, only one individual had a mixed infection with two species. In grey seals, the intensity varied between 27 and 4387 parasites (mean: 1338) and in ringed seals between 149 and 616 parasites (mean: 348). The parasites were removed from the intestines (ileum, cecum and colon), then fixed and stored in $70 \%$ ethanol for microscopic examination.

Ideally, acanthocephalans should be collected live and then relaxed in tap water to evert the proboscis, before fixation (Van Cleave 1953). However, in the present study the acanthocephalans were killed before collection, when they were frozen inside their seal hosts, and so could not be relaxed prior to preservation (Leidenberger \& Bäcklin 2008). Consequently, most specimens had a partially or fully introverted proboscis. Even in the few specimens with a fully everted proboscis, hooks were sometimes broken or obscured by host tissue debris. The three species of Corynosoma identified in the seal specimens from the Swedish Baltic Sea, C. magdaleni, C. semerme and C. strumosum, were discriminated primarily on basis of patterns of trunk spination. Morphometric and meristic data for the three taxa are listed in Table 2. Of the almost 1000 specimens of $C$. semerme examined, only 30 (14 females and 16 males) were in a suitable condition for morphological study, i.e., most conventional morphological characters were visible in each of these specimens (Table 2). C. magdaleni and C. strumosum were collected in smaller numbers (10 and 2 respectively), and it was not possible to find a single specimen of either species with a fully everted proboscis. Ten specimens ( 6 females and 4 males) of $C$. magdaleni and two 
Table 1. Material of Corynosoma magdaleni, C. semerme and C. strumosum studied from seals in the Baltic Sea and studied by SEM and/or LM. Abbreviation: yrs = years.

\begin{tabular}{|c|c|c|c|c|c|c|}
\hline Species & Host(s) & $\begin{array}{c}\text { Host gender } \\
\text { (age in yrs) }\end{array}$ & Locality & Habitat & Material & Number of specimens \\
\hline \multirow[t]{5}{*}{ C. magdaleni } & grey seals & $\begin{array}{l}\hat{O}(9) \\
\partial(12)\end{array}$ & $\begin{array}{c}\text { Stocka/Gävleborgs province, } \\
\text { Bothnian Sea }\end{array}$ & $\begin{array}{l}\text { ileum } \\
\text { colon }\end{array}$ & $\begin{array}{l}\text { SMNH-162973 } \\
\text { SMNH-162973 }\end{array}$ & $\begin{array}{c}4++, 1 \hat{0} \\
10\end{array}$ \\
\hline & & q $(0)$ & $\begin{array}{c}\text { Skärplinge/Uppsala province, } \\
\text { Bothnian Sea }\end{array}$ & colon & SMNH-162973 & $10^{1}$ \\
\hline & & $\begin{array}{l}\text { }+(2) \\
\text { q }(21)\end{array}$ & $\begin{array}{c}\text { Luelå/Norrbottens province, } \\
\text { Bothnian Bay }\end{array}$ & $\begin{array}{l}\text { ileum } \\
\text { colon }\end{array}$ & $\begin{array}{l}\text { SMNH-162973 } \\
\text { SMNH-162973 }\end{array}$ & $\begin{array}{l}1 \text { 우 } \\
1 \text { o }\end{array}$ \\
\hline & ringed seal & ㅇ (12) & $\begin{array}{c}\text { Tistersöarna, Luleå/ } \\
\text { Norrbottens province, } \\
\text { Bothnian Bay }\end{array}$ & ileum & SMNH-162973 & 1 우 \\
\hline & grey seal & (unknown) & $\begin{array}{l}\text { Åland, Bothnian Sea } \\
\text { (Nickol et al. 2002) }\end{array}$ & (unknown) & $\begin{array}{c}\text { HWML- 39480- } \\
1141-2 \\
\text { HWML- 39480- } \\
1041-3\end{array}$ & $\begin{array}{l}1 \text { o } \\
1 \text { o }\end{array}$ \\
\hline \multirow[t]{2}{*}{ C. semerme } & grey seals & $\widehat{\partial}(12)$ & $\begin{array}{c}\text { Stocka/Gävleborgs province, } \\
\text { Bothnian Sea }\end{array}$ & colon & $\begin{array}{l}\text { SMNH-162974 } \\
\text { SMNH-162975 }\end{array}$ & $\begin{array}{l}14 \text { 우우 } \\
10 \hat{\partial} \delta^{\lambda}\end{array}$ \\
\hline & & $\lesssim(19)$ & $\begin{array}{l}\text { Hudiksvall/Gävleborgs } \\
\text { province, Bothnian Sea }\end{array}$ & colon & SMNH-162976 & $6 \partial^{\lambda}$ \\
\hline \multirow[t]{3}{*}{ C. strumosum } & grey seals & $\hat{\partial}(9)$ & $\begin{array}{c}\text { Stocka/Gävleborgs province, } \\
\text { Bothnian Sea }\end{array}$ & colon & SMNH-162977 & 1 우 \\
\hline & & $\delta(21)$ & $\begin{array}{l}\text { Östhammar/Uppsala } \\
\text { provinces, Ålands hav }\end{array}$ & ileum & SMNH-162978 & $1 \hat{\sigma}$ \\
\hline & & (unknown) & $\begin{array}{l}\text { Åland, Bothnian Sea } \\
\text { (Nickol et al. 2002) }\end{array}$ & (unknown) & $\begin{array}{c}\text { HWML-39481- } \\
1158-2 \\
\text { HWML-39481- } \\
1142-4\end{array}$ & $\begin{array}{l}1 \text { o } \\
1 \hat{0}\end{array}$ \\
\hline
\end{tabular}

specimens (one of each gender) of C. strumosum were selected for morphological study on the basis that most taxonomic characters were visible in these worms.

Voucher specimens are deposited in the invertebrate collection of the Department of Zoology, Swedish Museum of Natural History (SMNH), Stockholm, Sweden (Nos. SMNH-162973-162978, SMNH172304-172310). Additionally, specimens of C. magdaleni and C. strumosum, collected by Nickol et al. (2002) from the Finish Baltic Sea, were borrowed from the University of Nebraska State Museum, Manter Laboratory of Parasitology (Nos. HWML 39480-39481).

For LM, 42 specimens stored in 70\% ethanol were transferred to pure glycerine by a slow evaporation method (Seinhorst 1959) and mounted on slides in glycerine. Observations were made with a Leitz Laborlux S microscope and measurements were taken with an ocular micrometer. All measurements (Fig. 2, Table 2) are in micrometres, unless otherwise noted. The range is followed by the mean value in parentheses. Width measurements represent the maximum width. The fore-trunk does not include the proboscis or neck and the hind-trunk not the bursa in males. Eggs of gravid females were measured through the body wall. Measurements of the proboscis hooks represent the length of the blade and the width of the base of the blade, as defined by Wayland (2010).

Copulatory caps were imaged using a Leica SP5 confocal microscope. Serial optical sections were obtained at $2.4 \mu \mathrm{m}$ intervals, using a plan-apochromat $10 \times / 0.4 \mathrm{NA}$ objective. A $405 \mathrm{~nm}$ laser was used for excitation, and autofluorescence was recorded in the range $415-514 \mathrm{~nm}$ using a photomultiplier tube. A maximum intensity projection was used to transform the serial optical sections into a $2 \mathrm{D}$ image. Image processing was performed in Fiji (Schindelin et al. 2012, 2015). 


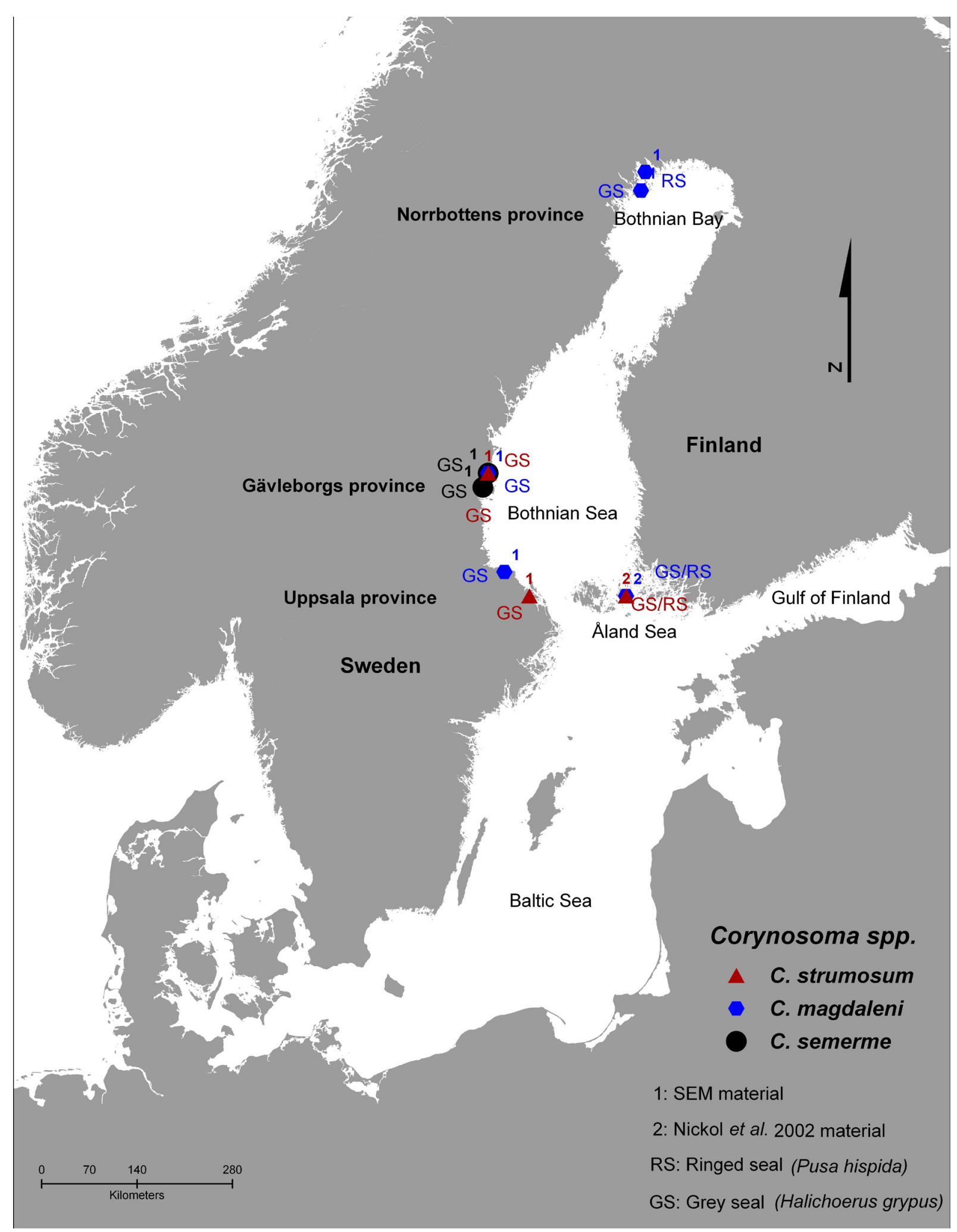

Fig. 1. Map of sampling localities. 
Table 2. Morphometric characters in Corynosoma magdaleni Montreuil, 1958, C. semerme (Forsell, 1904) Lühe, 1911 and C. strumosum (Rudolphi, 1802) Lühe 1904 from grey seals, Halichoerus grypus, in the Baltic Sea presented as mean and (range). All measurements in micrometre $(\mu \mathrm{m})$ unless otherwise noted. $\mathrm{n}=$ number of specimens measured is smaller than number of specimens available. $*=$ proboscis not fully everted.

\begin{tabular}{|c|c|c|c|c|c|c|}
\hline \multirow[b]{2}{*}{ Sex } & \multicolumn{2}{|c|}{ Corynosoma magdaleni } & \multicolumn{2}{|c|}{ Corynosoma semerme } & \multicolumn{2}{|c|}{ Corynosoma strumosum } \\
\hline & ㅇ & $\delta^{2}$ & q & 0 & 우 & 0 \\
\hline Number of specimens & 6 & 4 & 14 & 16 & 1 & 1 \\
\hline Body length (mm) & $4.36(3.67-5.11)$ & $3.61(2.53-4.39)$ & $2.50(1.83-3.13)$ & $2.32(1.91-2.73)$ & 4.90 & 5.67 \\
\hline Fore-trunk length (mm) & $0.86(0.74-0.95)$ & $0.92(0.73-1.20)$ & $1.11(0.77-1.49)$ & $1.00(0.78-1.46)$ & 0.91 & 1.43 \\
\hline Fore-trunk width (mm) & $0.58(0.50-0.68)$ & $0.49(0.40-0.58)$ & $0.95(0.64-1.21)$ & $0.89(0.72-1.04)$ & 0.58 & 0.99 \\
\hline Hind-trunk length (mm) & $3.50(2.86-4.37)$ & $2.69(1.81-3.19)$ & $1.39(0.63-1.79)$ & $1.32(0.85-1.53)$ & 3.99 & 4.24 \\
\hline Hind-trunk width (mm) & $0.35(0.30-0.41)$ & $0.34(0.26-0.46)$ & $0.68(0.39-0.86)$ & $0.63(0.51-0.79)$ & 0.35 & 0.6 \\
\hline $\begin{array}{l}\text { Trunk spines length } \\
\text { (fore-trunk) }\end{array}$ & $30(20-40)$ & $32(30-40)$ & $30(10-50)$ & $34(20-50)$ & 20 & 30 \\
\hline Neck length & $\begin{array}{c}165 \\
(150-190)(\mathrm{n}=3)\end{array}$ & $113(n=2)$ & $\begin{array}{c}175 \\
(90-280)(\mathrm{n}=10)\end{array}$ & $\begin{array}{c}168 \\
(140-230)(n=13)\end{array}$ & - & 160 \\
\hline Neck width & $\begin{array}{c}221 \\
(210-240)(\mathrm{n}=3)\end{array}$ & $\begin{array}{c}153(110-190) \\
\quad(\mathrm{n}=2)\end{array}$ & $\begin{array}{c}314 \\
(240-410)(\mathrm{n}=10)\end{array}$ & $\begin{array}{c}262 \\
(230-300)(\mathrm{n}=13)\end{array}$ & - & 350 \\
\hline Proboscis length & $\begin{array}{c}{[306(250-360)]^{*}} \\
(\mathrm{n}=2)\end{array}$ & {$[219(190-250)]^{*}$} & $\begin{array}{c}393 \\
(280-510)(\mathrm{n}=7)\end{array}$ & $\begin{array}{c}472 \\
(360-610)(n=7)\end{array}$ & {$[140]^{*}$} & {$[270]^{*}$} \\
\hline Proboscis width & $176(140-200)$ & $144(140-150)$ & $242(180-290)$ & $\begin{array}{c}226 \\
(190-260)(\mathrm{n}=14)\end{array}$ & 140 & 190 \\
\hline $\begin{array}{l}\text { Proboscis receptacle } \\
\text { length }\end{array}$ & $490(n=1)$ & $\begin{array}{c}666(640-690) \\
(n=2)\end{array}$ & $\begin{array}{c}941 \\
(690-1230)(n=8)\end{array}$ & $\begin{array}{c}776 \\
(630-1250)(n=10)\end{array}$ & - & 790 \\
\hline $\begin{array}{l}\text { No. of longitudinal } \\
\text { rows of hooks }\end{array}$ & $18(16-20)$ & $17(16-20)$ & $23(20-25)$ & $23(22-24)$ & 20 & 18 \\
\hline $\begin{array}{l}\text { No of hooks in each } \\
\text { row }\end{array}$ & $10(8-11)$ & $8(8-10)$ & $11(10-12)$ & $12(10-14)$ & 10 & 10 \\
\hline $\begin{array}{l}\text { Subdivision of hooks in } \\
\text { each row }\end{array}$ & & & & $\begin{array}{l}-6) \\
-3) \\
-5)\end{array}$ & & \\
\hline $\begin{array}{l}\text { Hook length, anterior } \\
\text { series }\end{array}$ & $30(\mathrm{n}=2)$ & $38(30-50)(\mathrm{n}=2)$ & $39(20-50)(\mathrm{n}=9)$ & $41(10-60)(n=15)$ & 20 & 30 \\
\hline $\begin{array}{l}\text { Hook length, middle } \\
\text { series }\end{array}$ & $47(20-50)$ & $44(40-50)$ & $59(30-80)$ & $60(30-80)(n=15)$ & 30 & 60 \\
\hline $\begin{array}{l}\text { Hook length, posterior } \\
\text { series }\end{array}$ & $29(20-40)(\mathrm{n}=5)$ & $24(20-30)(\mathrm{n}=2)$ & $28(10-40)(n=12)$ & $27(10-40)(n=13)$ & 20 & 30 \\
\hline Genital spines length & - & $17(\mathrm{n}=3)$ & - & $43(30-50)$ & - & 20 \\
\hline Testes length & - & - & - & $\begin{array}{l}283(150-400)(\mathrm{n} \\
=13)\end{array}$ & - & 430 \\
\hline Testes width & - & - & - & $\begin{array}{c}223(140-330)(\mathrm{n} \\
=13)\end{array}$ & - & 190 \\
\hline Cement glands length & - & $88(\mathrm{n}=1)$ & - & $165(90-230)(\mathrm{n}=12)$ & - & 150 \\
\hline Cement glands width & - & $50(\mathrm{n}=1)$ & - & $\begin{array}{c}164(100-240)(\mathrm{n} \\
=12)\end{array}$ & - & 170 \\
\hline $\begin{array}{l}\text { Saefftigen's pouch } \\
\text { length }\end{array}$ & - & $\begin{array}{c}566(240-890) \\
\quad(\mathrm{n}=2)\end{array}$ & - & $\begin{array}{c}214(140-290)(\mathrm{n} \\
=12)\end{array}$ & - & 480 \\
\hline $\begin{array}{l}\text { Saefftigen's pouch } \\
\text { width }\end{array}$ & - & $\begin{array}{l}81(60-100)(\mathrm{n} \\
=2)\end{array}$ & - & $126(80-210)(\mathrm{n}=12)$ & - & 70 \\
\hline Bursa length & - & $\begin{array}{c}258(160-390) \\
(\mathrm{n}=3)\end{array}$ & - & $385(290-510)(\mathrm{n}=3)$ & - & 190 \\
\hline Bursa width & - & $\begin{array}{c}271(160-440) \\
(\mathrm{n}=3)\end{array}$ & - & $440(350-490)(\mathrm{n}=3)$ & - & 220 \\
\hline Egg length & $57(50-60)(\mathrm{n}=5)$ & - & $\begin{array}{l}91(40-120) \\
(\mathrm{n}=10)\end{array}$ & - & - & - \\
\hline Egg width & $17(n=5)$ & - & $27(10-40)(\mathrm{n}=10)$ & - & - & - \\
\hline
\end{tabular}




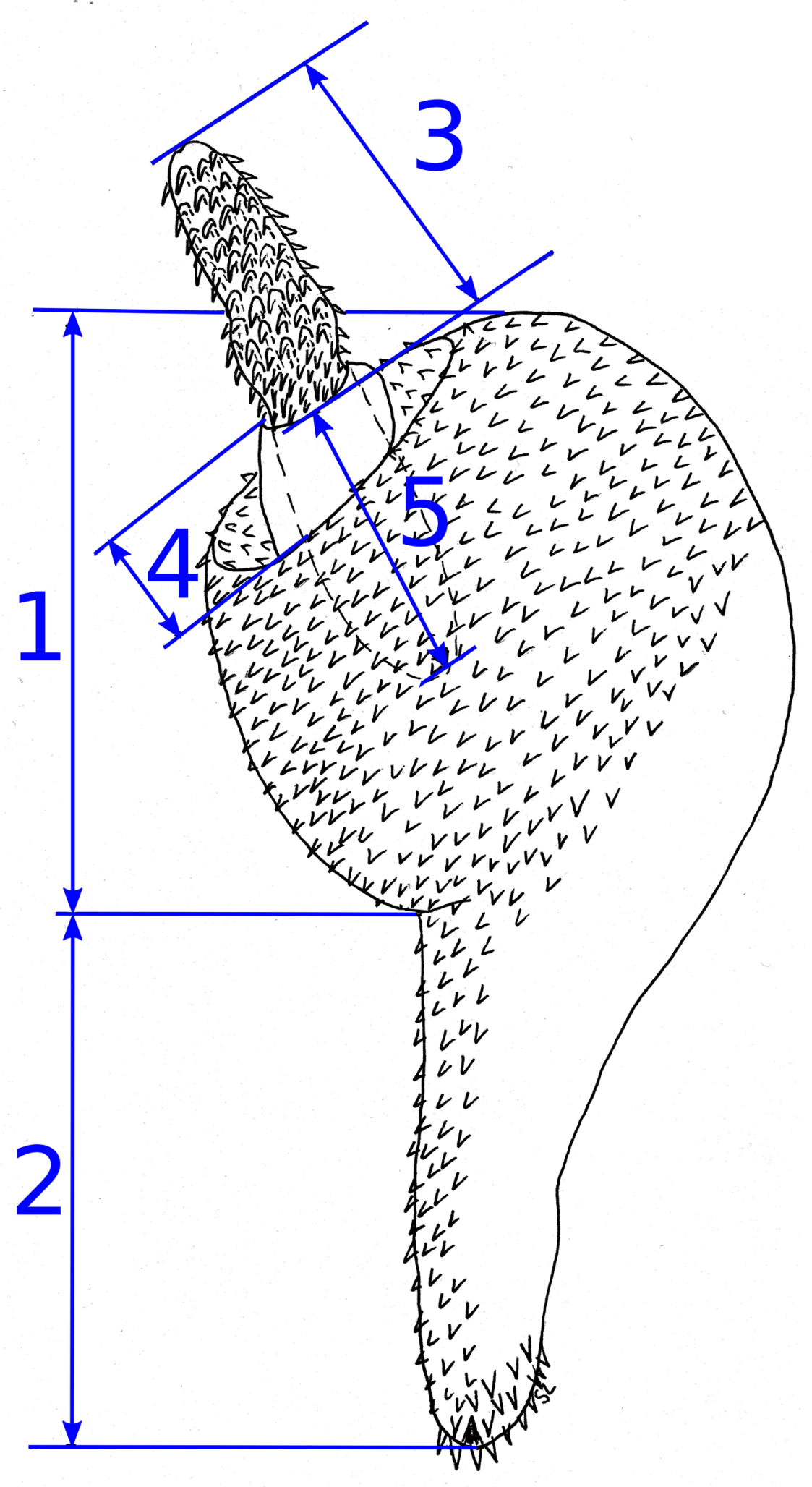

Fig. 2. Schematic diagram of praesoma and trunk of a male of Corynosoma semerme illustrating the length measurements recorded from all three species of Coryonosma; internal organs except proboscis receptacle excluded. 1 = fore-trunk. 2 = hind-trunk. 3 = proboscis. $4=$ neck. $5=$ proboscis receptacle. 
For SEM, 41 specimens fixed in 70\% ethanol were dehydrated through an ethanol series. Specimens were critical point dried in liquid $\mathrm{CO}_{2}$, mounted on stubs, gold-plated under vacuum to a thickness of $20 \mathrm{~nm}$ in an Agar High Resolution Sputter Coater Model 20, and examined in a Hitachi S-4300 SEM at an accelerating voltage of $10 \mathrm{kV}$ and photographed by digital imaging software. Figure plates were prepared using FigureJ (Mutterer \& Zinck 2013).

\title{
Institutional abbreviations
}

HWML = University of Nebraska State Museum, Manter Laboratory of Parasitology, Lincoln, USA $\mathrm{SMNH}=$ Swedish Museum of Natural History, Stockholm, Sweden

\section{Results}

\author{
Phylum Acanthocephala Rudolphi, 1802 \\ Class Palaeacanthocephala Meyer, 1931 \\ Order Polymorphida Petrochenko, 1956 \\ Family Polymorphidae Meyer, 1931
}

Genus Corynosoma Lühe, 1904

The morphology of all three species conformed to the generic diagnosis of Corynosoma according to Lühe (1904, 1911), Van Cleave (1953), Arai (1989) and Aznar et al. (2006). The genus is characterized by a small body size, comprising a clubbed fore-trunk and a cylindrical hind-trunk. Trunk spines on the anterior and ventral surface of the fore-trunk. Neck trapezoid, short and spineless; can be retracted into fore-trunk. Proboscis subcylindrical, enlarged midway along its length or just posterior to the midpoint. Proboscis hooks arranged in longitudinal rows. Posterior 3-5 hooks in a longitudinal row without roots; all other hooks with simple, unbranched roots. Largest hooks occur on broadest part of proboscis. Proboscis receptacle double-walled. Lemnisci shorter than proboscis receptacle, broad and leaf-like. Gonopore terminal or slightly subterminal in both genders. Male reproductive system either confined to the hind-trunk or extending into posterior part of fore-trunk. Paired testes elongate-oval, partially overlapping. Six pyriform cement glands. Eggs fusiform, with relatively short polar prolongations of the thickened shell membrane, filling body cavity of gravid females. Gonopore of female sometimes covered by a copulatory cap.

Corynosoma magdaleni Montreuil, 1958

Figs 3-4, Table 2

\section{Diagnosis}

Corynosoma magdaleni is characterised by a body $3.67-5.11 \mathrm{~mm}$ long in females and $2.53-4.39 \mathrm{~mm}$ long in males, a slender trapezoid neck structure, spines covering most of fore-trunk, spines covering more than half the length of ventral surface of hind-trunk, proboscis with 16-20 longitudinal rows of hooks in both genders with 8-11 hooks in each row in females and 8-10 hooks in each row in males.

Material examined (see Table 1 and Fig. 1)

FINLAND • 1 ㅇ; Åland, Bothnian Sea; HWML- 39480-1141-2 • 1 đ̊; Åland, Bothnian Sea; HWML39480-1041-3.

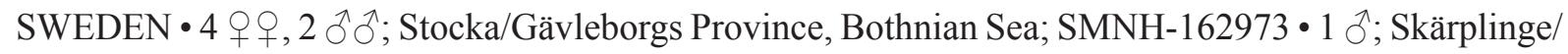
Uppsala Province, Bothnian Sea; SMNH-162973 • 1 q, 1 đ̊; Luelå/Norrbottens Province, Bothnian Bay; SMNH-162973 • 1 क; Tistersöarna, Luleå/Norrbottens Province, Bothnian Bay; SMNH-162973. 
Corynosoma semerme (Forsell, 1904) Lühe, 1911

Figs 5-6, Table 2

\section{Diagnosis}

Corynosoma semerme is characterised by a body $1.83-3.13 \mathrm{~mm}$ long in females and $1.91-2.73 \mathrm{~mm}$ long in males, a robust trapezoid neck structure, spines covering most of fore-trunk, spines covering entire ventral surface of hind-trunk, proboscis with 22-25 longitudinal rows of hooks with 10-12 hooks in each row in females and 22-24 longitudinal rows of hooks with 10-14 hooks in each row.

Material examined (see Table 1 and Fig. 1)

SWEDEN • 14 q ; ; Stocka/Gävleborgs Province, Bothnian Sea; SMNH-162974 • 10 ổ; same data

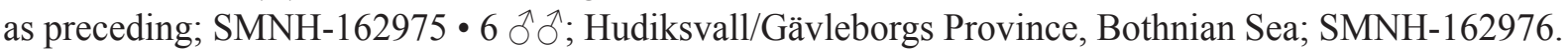

\section{Corynosoma strumosum (Rudolphi, 1802) Lühe, 1904}

Figs $7-8$, Table 2

\section{Diagnosis}

Corynosoma strumosum is characterised by a body $4.90 \mathrm{~mm}$ long in females and $5.67 \mathrm{~mm}$ long in males, a robust trapezoid neck structure, spines covering most of fore-trunk, spines covering anterior third
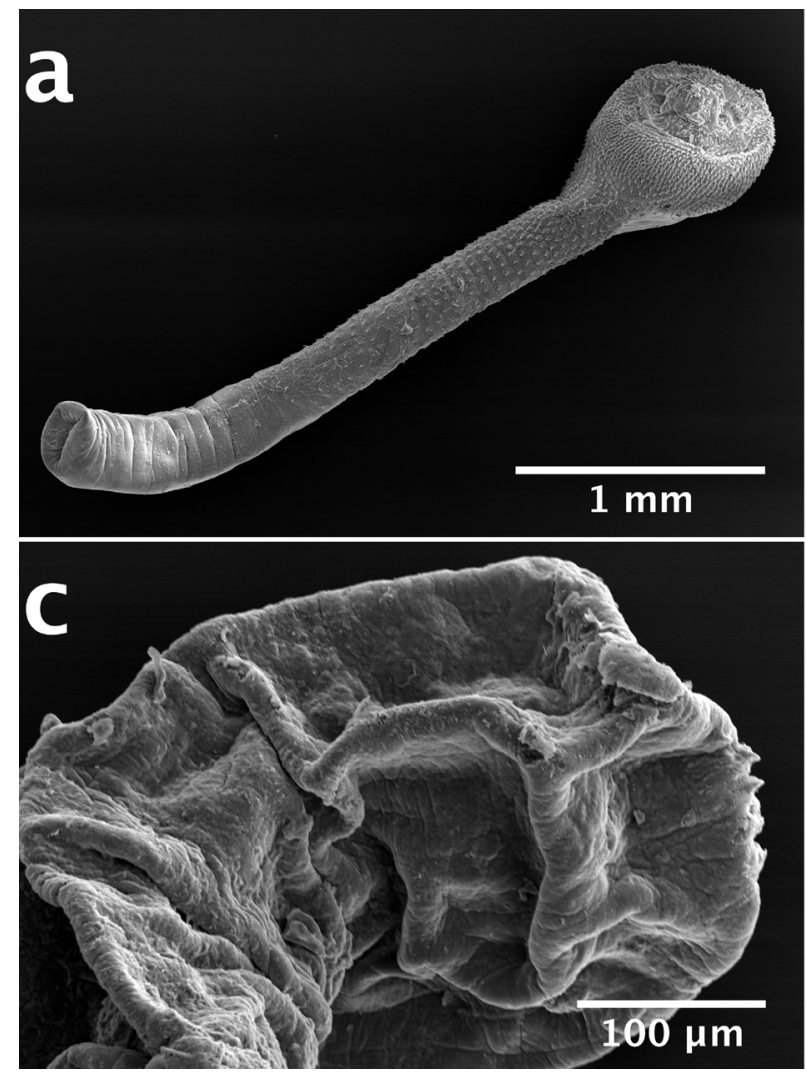
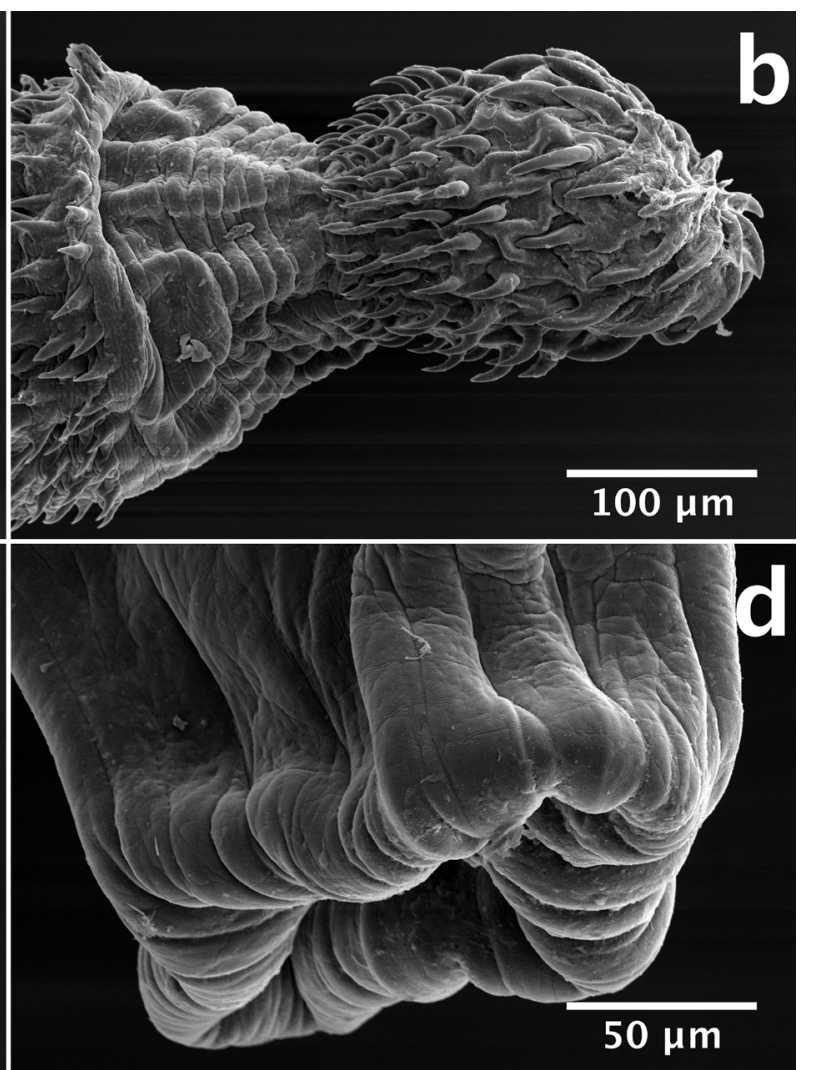

Fig. 3. SEM micrographs of Corynosma magdaleni from grey seals, Halichoerus grypus, in the Swedish Baltic Sea. a. o, entire worm, ventro-lateral view, from the Bothnian Bay, Norrbotten, Luleå. Ventral spination extends over more than half the length of the hind-trunk. b. Proboscis of a $q$ showing the spineless neck and the arrangement of the hooks. c. Posterior end of a $\delta$ showing the extended copulatory bursa. d. Posterior end of a $q$ in which the gonopore has been retracted into the gential vestibule. 

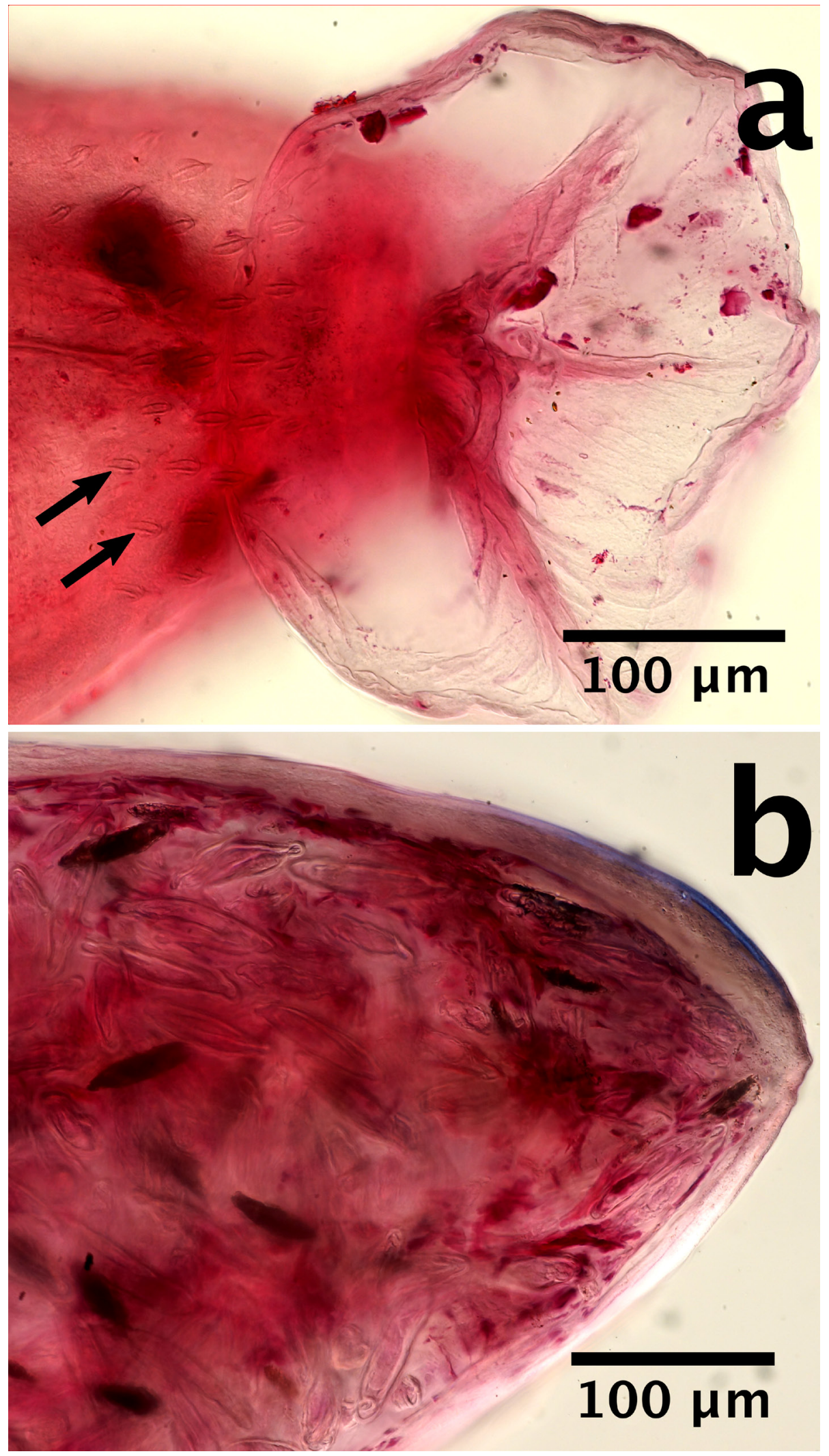

Fig. 4. LM micrographs showing posterior end of Corynosoma magdaleni from a grey seal, Halichoerus grypus, from the archipelago of Åland (Finland). a. $\hat{\delta}$ showing everted bursa and genital spine (arrows)

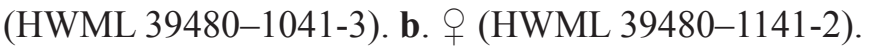



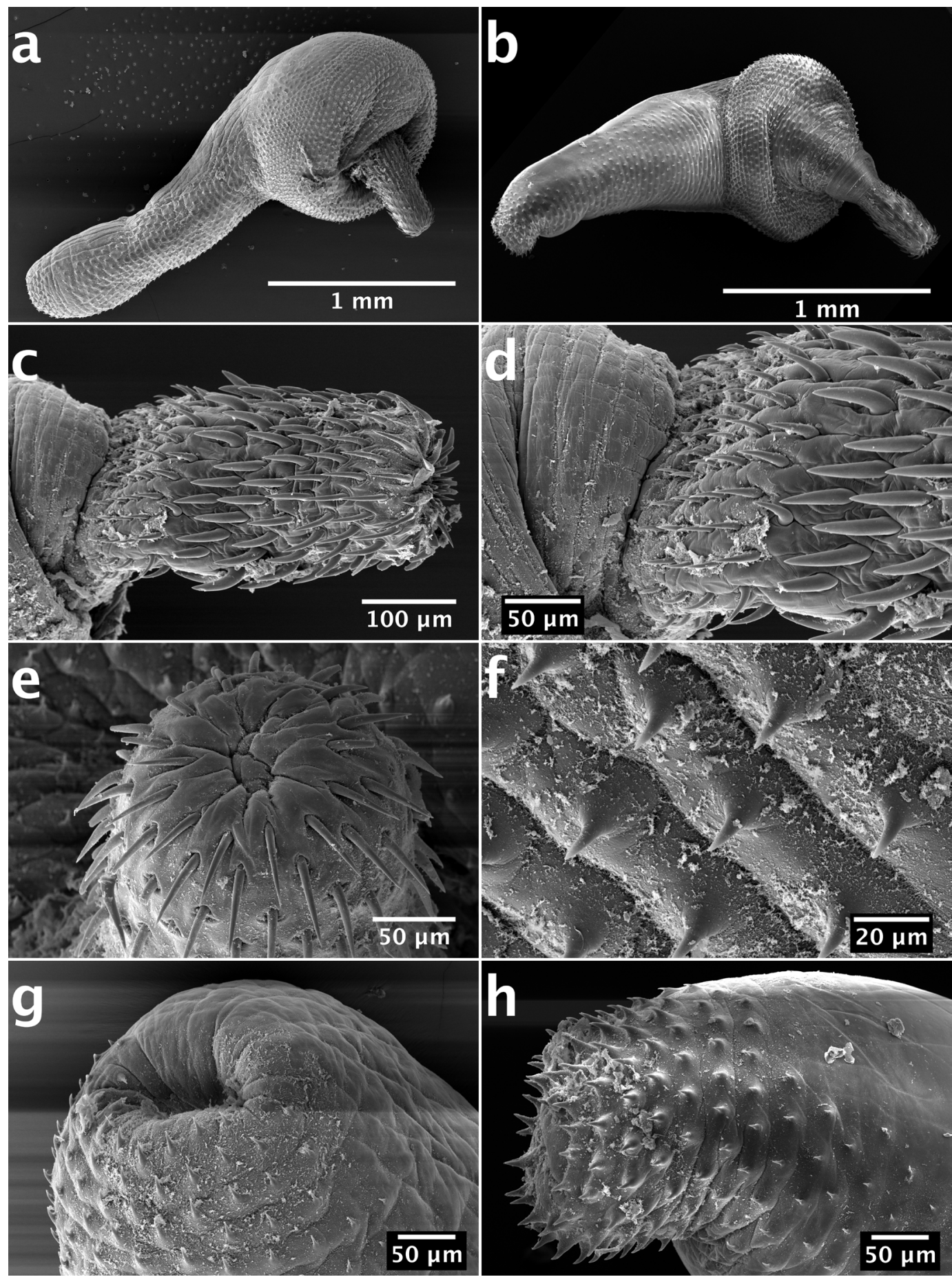

Fig. 5. SEM micrographs of Corynosoma semerme from grey seals, Halichoerus grypus, in the Swedish Baltic Sea. a. $ᄋ$, entire worm, ventro-lateral view, from the Bothnian Sea, Hälsingland, Stocka. Spines cover the entire ventral surface of the hind-trunk. b. 0 , whole worm, ventral view, from the Bothnian Sea, Hälsningland, Stocka. Ventral spination of the entire hind-trunk and numerous genital spines. c. Proboscis of a $q$, ventral view, showing the arrangement of the hooks. d. Base of proboscis of a $q$, lateral view, showing the spineless neck and the posterior and middle series of hooks. e. Anterior end of proboscis of a + showing the bare tip. f. Trunk spines of the fore-trunk of a $\hat{\partial}$, ventral view. g. Posterior end of a $O$ showing the trunk-spines that extend over the ventral surface as far as the gonopore. $\mathbf{h}$. Posterior end of a $\widehat{\delta}$ with numerous genital spines. 
of ventral surface of the hind-trunk, proboscis with 20 longitudinal rows of hooks in females and 18 longitudinal rows of hooks in males with 10 hooks in each row in both genders.

Material examined (see Table 1 and Fig. 1)

FINLAND • 1 q; Åland, Bothnian Sea; HWML- 39481-1158-2 • 1 đ̊; Åland, Bothnian Sea; HWML39481-1142-4.

SWEDEN • 1 \%; Stocka/Gävleborgs Province, Bothnian Sea; SMNH-162977 • 1 đ; Östhammar/ Uppsala Province, Ålands hav; SMNH-162978.
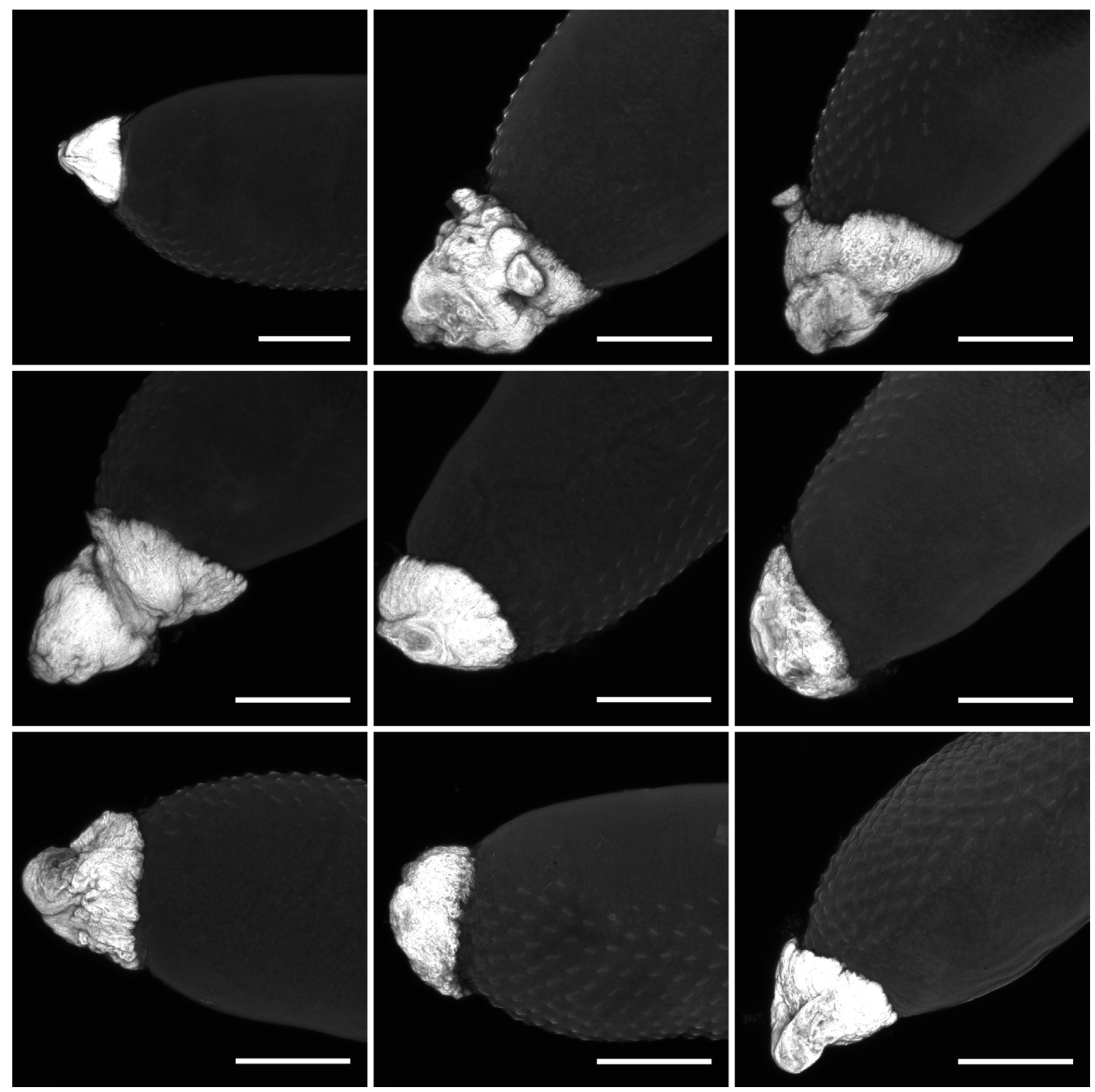

Fig. 6. Variation in the morphology and size of copulatory caps found on $q$ Corynosoma semerme from a ringed seal, Pusa hispida, in the Swedish Baltic Sea. Images are maximum intensity projections of confocal image stacks. The copulatory caps show strong autofluorescence when excited with a $405 \mathrm{~nm}$ laser. All scalebars represent $200 \mu \mathrm{m}$. 


\section{Comparative analysis of conventional morphological characters}

In all three species, spines cover most of the fore-trunk, but are only found on the ventral surface of the hind-trunk. The extent of spine coverage of the ventral surface of the hind-trunk shows interspecific variation and is the most useful character for discriminating the three species. In C. magdaleni, spines cover more than half the length of the hind-trunk, and the density of spines decreases from anterior to posterior (Fig. 3a). Corynosoma semerme exhibits spines over the entire ventral surface of the hind-trunk (Fig. 5a-b). Spines cover only the anterior third of the ventral surface of the hind-trunk in C. strumosum (Fig. 7a-b).

Corynosoma semerme can be distinguished from the other two taxa on the basis of having more longitudinal rows of hooks (22-25 vs $16-20$ in C. magdaleni and 18-20 in C. strumosum). In C. magdaleni, longitudinal rows of hooks are punctuated by a gap between the middle series of 2-4 large, robust hooks and the proximal series of 3-4 short, slender hooks (Fig. 3b); this gap was not observed in the other two taxa. The trapezoid neck structure is robust in C. semerme (Fig. $5 \mathrm{c}-\mathrm{d}$ ) and C. strumosum (Fig. 7c), but more slender in C. magdaleni (Fig. 3b).

Genital spines were observed surrounding the gonopore of males in all three taxa (e.g., Fig. 5h). These genital spines are larger than the trunk spines (Table 2). Genital spines were not observed in any of the female acanthocephalans. However, the gonopore was retracted into the genital vestibule in many
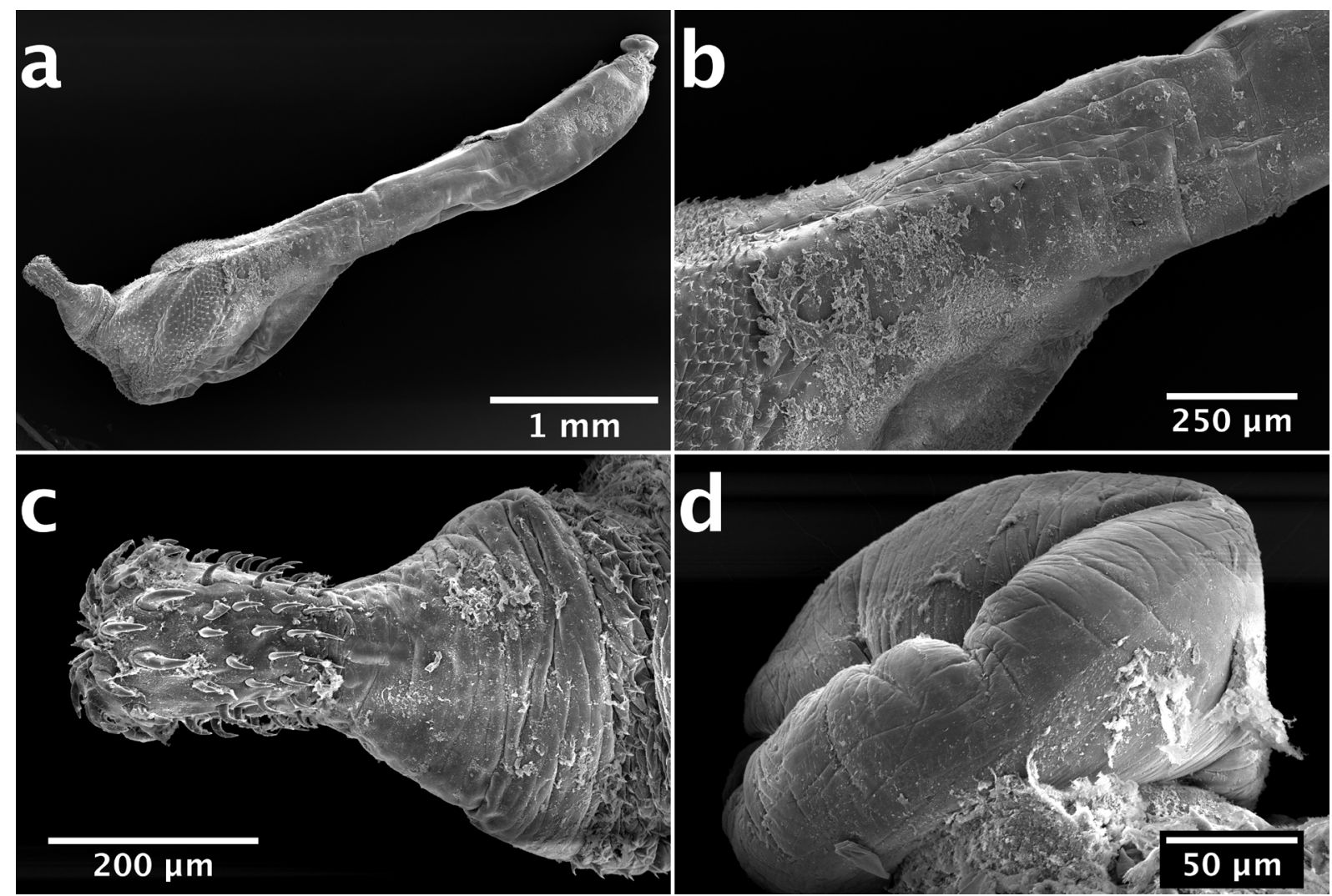

Fig. 7. SEM micrographs of Corynosoma strumosum from grey seals, Halichoerus grypus, in the Swedish Baltic Sea. a. ô, whole worm, ventro-lateral view, from the Bothnian Sea, Uppland, Östhammar. b. Ventral spination on the hind-trunk of a $\widehat{\sigma}$ restricted to one-third of its length only. c. Proboscis of a $\hat{\delta}$, lateral view, showing the spineless neck and the arrangement of the hooks. d. Posterior end of a $\hat{\sigma}$ showing the extended copulatory bursa. 
females (Fig. 3d), which would obscure genital spines if present. In female C. semerme, the trunk spines extend as far as the gonopore (Fig. $5 \mathrm{~g}$ ), but do not differentiate into distinctive genital spines or surround the genital pore as they do in the males (Fig. 5h). Therefore, we consider genital spines to be absent in C. semerme of the Baltic Sea.

Egg size can aid the discrimination of gravid females of $C$. magdaleni from those of $C$. semerme, the former species having shorter eggs (50-60 vs 40-120 $\mu \mathrm{m})$. The only female specimen of $C$. strumosum found in this study was not gravid and so we were unable to measure the eggs of this species.

\section{Copulatory caps}

Copulatory caps were observed covering the gonopore of some females of C. semerme (Fig. 6). These copulatory caps showed considerable variation in size and all were strongly autofluorescent when illuminated with light of a wavelength of $405 \mathrm{~nm}$. Copulatory caps were not observed on male C. semerme or on any specimens of the other two species examined.

\section{Study of the material from Finnish Baltic Sea (Nickol et al. 2002)}

Nickol et al. (2002) stated that their "descriptions of C. magdaleni and C. strumosum are based on 80 specimens that were fully extended or were extended enough to show most of the anatomical features". Surprisingly, very little of their material was preserved and deposited as voucher specimens: four slides, each with one male and one female of each species. The material was of limited use for our morphological studies. One male of C. magdaleni (HWML 39480-1041-3) had a fully everted proboscis which facilitated the measurement of hook morphometrics in two complete longitudinal rows of hooks (one on
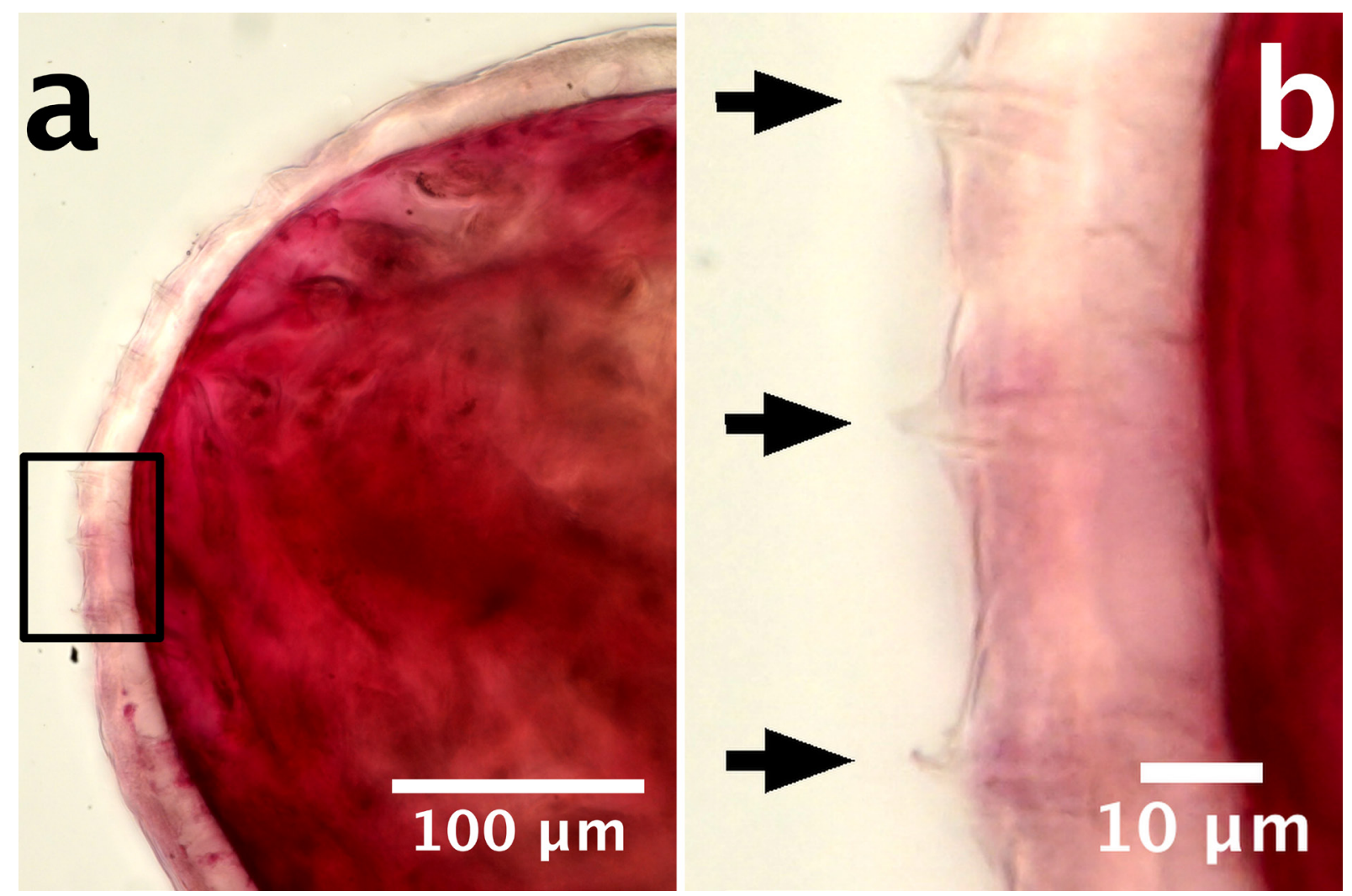

Fig. 8. LM micrographs of genital spines of a $q$ Corynosoma strumosum (HWML 39481-1158-2) from a grey seal, Halichoerus grypus, from the archipelago of Åland (Finland). a. Posterior of trunk. b. Enlargement of rectangular region in subfigure a. 
the dorsal surface or the proboscis and the other on the ventral). The partially inverted proboscides of the other three specimens obscured the anterior hooks, preventing analysis of hook patterns. It is important to note that the material of Nickol et al. (2002) was "stained with Mayer's carmalum, dehydraded in ethanol, cleared in xylene and mounted in Canada balsam", which differed from our preparation method (see Material and methods). Therefore comparisons of morphometric data between the two studies should be treated with caution.

Genital spines were clearly visible in the male C. magdaleni (HWML 39480-1041-3) (Fig. 4a), which also agrees with the description by Montreuil (1958). In the female (HWML 39480-1141-2), genital spines were not observed (Fig. 4b), which agrees with the description by Montreuil (1958) ("small number of spines (2 to 10) in less than the half of the females") and with the description by Nickol et al. (2002) ("absent in most females", but contrary to their fig. 2). We observed a few genital spines in the C. strumosum female (HWML 39481-1158-2) (Fig. 8), which concurs with the descriptions by Van Cleave (1953) and Nickol et al. (2002). Genital spines were not visible on the male C. strumosum (HWML 39481-1142-4), but the genital pore was introverted into the genital vestibule, possibly obscuring any spines that might be present.

\section{Sexual dimorphism and interspecific variation in trunk morphology}

Both C. magdaleni and C. semerme exhibited subtle sexual dimorphism in trunk shape. In C. magdaleni, trunk length, hind-trunk length and fore-trunk width were typically larger in gravid females than in males (Table 2). In C. semerme, fore-trunk length and width showed the most evidence of sexual dimorphism. Males were typically smaller than gravid females. Corynosoma magdaleni and C. semerme appear to differ in trunk shape. Corynosoma magdaleni has a longer, but narrower fore-trunk and hind-trunk. These differences can be observed in both females and males (Table 2). The trunk shape of C. strumosum is similar to that of C. magdaleni.

\section{Discussion}

\section{Conventional morphological characters}

Overall, our morphological measurements of the three species of Corynosoma agree with those found in the literature. For example, in the original description of C. magdaleni, Montreuil (1958) noted that the females were slightly larger than the males, and this sexual dimorphism in size was observed in the present study. Montreuil (1958) also noted that the neck exhibited greater extension in females than in males, a characteristic also observed in C. magdaleni and C. semerme in our study. The specimens of C. semerme males $(2.60 \pm 0.32 \mathrm{~mm}, \mathrm{n}=173)$ and females $(2.93 \pm 0.39 \mathrm{~mm}, \mathrm{n}=172)$ found by Helle \& Valtonen (1981) were somewhat larger than those encountered in the present study. Helle \& Valtonen (1981) reported that the total body length of $C$. strumosum from ringed seals of the Bothnian Bay was $4.71 \pm 0.68 \mathrm{~mm}$ for males $(\mathrm{n}=373)$ and $5.34 \pm 0.77 \mathrm{~mm}$ for females $(\mathrm{n}=390)$. Popov \& Fortunato $(1987)$, Nickol et al. (2002) and Kaimoto et al. (2018) also reported that females of C. strumosum were larger than males. However, in our material, that consists only of one individual per gender, the male was larger than the female (Table 2). While most studies in Europe (except Lühe 1911), including the present one, describe slight differences between the body size of the genders, sexual dimorphism is rarely reported in the North American literature (Van Cleave 1953). Waindok et al. (2018) and Nickol et al. (2002) did not separate the measurements for males and females.

Populations of $C$. semerme from the coast of Sweden and the Gulf of Finland appear to differ in the number of longitudinal rows of hooks, the former displaying 20-25 (present study) and the latter 26 (Forssell 1904). However, the number of hooks observed in each row seems very similar: 10-14 (this study) vs 12-14 (Forssell 1904). Lühe (1911) described the German material with 24-26 longitudinal rows and 13 hooks in each row, while Van Cleave (1953) described the North American material with 
22-24 rows of 12-13 hooks each. For C. magdaleni, the examined proboscis armature of Swedish worms differed slightly from the Canadian material described by Montreuil (1958). The Swedish material has fewer longitudinal rows and hooks in each row than the Canadian material (rows: 16-20 vs 17-23; hooks: 8-11 vs 9-11) (see also Table 2), but agrees with the description by Waindok et al. (2018) who found 16-19 rows of hooks for C. magdaleni. For C. strumosum, Rudolphi (1802) described a short and cylindrical proboscis with 16 and Lühe (1911) with 18 longitudinal rows of hooks for material collected in Germany. Our Swedish material showed 18-20 rows of hooks with 10 hooks each (Table 2). This agrees with the German studies mentioned above, while the North American material exhibited up to 11 hooks in each row (Van Cleave 1953). The extensive study by Popov \& Fortunato (1987) showed for C. strumosum material from ringed seals variations between 15 and 21 longitudinal rows with 8-12 hooks in each row.

Overall, cross-study comparisons suggest that the number of longitudinal rows and number of hooks in each row show intraspecific variation related to geographical region and definitive host. However, in the absence of molecular data we cannot be certain that this apparent intraspecific variation is not in fact interspecific variation among cryptic species (Väinölä et al. 1994; Steinauer et al. 2007; Waindok et al. 2018). Intraspecific morphological variation related to host has been observed in Corynosoma hannae Zdzitowiecki, 1984 (see Hernández-Orts et al. 2017).

The genital spines may be obscured if the tip of the tail is retracted into the genital vestibule (Van Cleave 1945). Males have numerous genital spines around the tail (e.g., Figs 2, 5b, 5h), which vary in size between the species (see Table 2) and clearly differ from the trunk spines. We could, however, not observe any genital spination in females in the Swedish material (e.g., Fig. 5g), but was seen in the prepared Finnish female of C. strumosum analysed by Nickol et al. (2002) (Fig. 8). Forssell (1904, 1905) and Lühe (1911) did not describe genital spines in Finnish and German females of C. semerme and C. strumosum. By contrast, some genital spines in females were described for the North American material (e.g., Montreuil 1958 for C. magdaleni). Van Cleave (1953) did observe the same pattern for females of $C$. strumosum ("often introverted into the genital vestibule and not observable from the surface"). He suggested that the few spines occasionally found in females may be lost with the copulatory cap. This could be one explanation why some authors did not observe and describe them.

Another possibility to explain the differences observed, may be morphological divergence between the Northern European and North American material. Our own observations disagree with the description of C. strumosum by Nickol et al. (2002) ("genital spines long in both sexes"). The study by Nickol et al. (2002) did not separate the measurements for males and females, and combined the Finnish results with those from Van Cleave (1953) and Montreuil (1958), both studies from North American material. It would have been more helpful for us to compare the Swedish results with a pure Finnish data set which is missing. The morphological description by Nickol et al. (2002) should be handled with caution or avoided, because they combined specimens from two different geographical areas (North America and the Baltic Sea). Popov \& Fortunato (1987) did not observe genital spines in 80 female individuals of C. strumosum collected from the Chaun Bay in the Eastern Siberian Sea, although genital spines were present in all other collected samples $(\mathrm{n}=500)$. Amin et al. (2011: fig. 4) presented one SEM picture of female genital spines for an acanthocephalan identified as C. strumosum from the Caspian seal, Pusa caspica Gmelin, 1788, from the Caspian Sea. However, specimens of Corynosoma from Caspian seals are likely to be Corynosoma caspicum (Golvan \& Mokhayer, 1973) (see García-Varela et al. 2005).

\section{Trunk shape}

Corynosoma magdaleni and C. strumosum share a similar trunk shape, which is longer and more slender than that of $C$. semerme. The phenotypic divergence of $C$. semerme from the other two species reflects the phylogenetic relationships of the three taxa; molecular genetic data have revealed that C. magdaleni 
and C. strumosum have a closer affinity to each other, than to C. semerme (Waindock et al. 2018; Lisitsyna et al. 2019).

In the majority of acanthocephalans, the proboscis is the primary organ of attachment to the intestinal wall of the definitive host; and, therefore, adaptive radiation is often expressed in divergence of proboscis morphology. However, in Corynosoma both the trunk and proboscis anchor the acanthocephalan to the wall of the intestine (Aznar et al. 1999). We might speculate that adaptation to different regions of the digestive tract might be accompanied by changes in trunk shape and spination. Spine coverage may be linked to trunk shape (Hernández-Orts et al. 2012), but further analyses are needed.

\section{Copulatory caps}

Copulatory caps were only observed on females of $C$. semerme. The copulatory caps are formed from a substance produced by the cement gland secretions of male worms (Dezfuli et al. 1999) and are thought to prevent further inseminations and thus sperm competition (Crompton 1985). The considerable variation in the size of the copulatory caps may be random; or, alternatively, might represent differences between males in the allocation of resources to prevent sperm competition. The copulatory caps were strongly autofluorescent when illuminated with a $405 \mathrm{~nm}$ laser. Dezfuli et al. (1998) demonstrated that the cement glands of Pomphorhynchus laevis (Zoega in Müller, 1776) produce a protein with a molecular weight of $23 \mathrm{kDa}$. However, little else is known about the composition of acanthocephalan copulatory caps.

\section{Future work}

Tandem morphological and molecular analyses are required to investigate the diversity of species of Corynosoma and to identify the best phenotypic characters for discriminating the species found. Given the difficulties of retrieving high quality specimens from dead definitive hosts, alternative sampling methods should be investigated, such as rectoscopy or intestinal biopsy of anaesthetized seals.

\section{Acknowledgements}

We thank Dr O. Holovachov for support with the SEM preparation and photographing some of the material and S.L. Gardner and G. Racz at the University of Nebraska State Museum, Manter Laboratory of Parasitology, USA, for arranging the loan of the voucher specimens of Corynosoma species. The Swedish Taxonomy Initiative (grant \# dha 2017.4.3-16) and Riksmusei Vänner foundation funded this project.

\section{References}

Amin O.M., Heckmann R.A., Halajian A. \& El-Naggar A.M. 2011. The morphology of an unique population of Corynosoma strumosum (Acanthocephala, Polymorphidae) from the Caspian seal, Pusa caspica, in the land-locked Caspian Sea using SEM, with special notes on histopathology. Acta Parasitologica 56: 438-445. https://doi.org/10.2478/s11686-011-0070-6

Arai H.P. 1989. Acanthocephala. In: L. Margolis \& Z. Kabata (eds), Guide to the Parasites of Fishes of Canada. Part III: 1-41. Canadian Special Publication of Fisheries and Aquatic Sciences 107, Ottawa.

Aznar F.J., Bush A.O., Fernández M. \& Raga J. A. 1999. Constructional morphology and mode of attachment of the trunk of Corynosoma cetaceum (Acanthocephala: Polymorphidae). Journal of Morphology 241: 237-49. https://doi.org/10.1002/(SICI)1097-4687(199909)241:3<237::AID-JMOR6>3.0.CO;2-A

Aznar F.J., Pérez-Ponce de Léon G. \& Raga J.A. 2006. Status of Corynosoma (Acanthochephala: Polymorphidae) based on anatomical, ecological, and phylogenetic evidence, with the erection of Pseudocorynosoma n. gen. Journal of Parasitology 92: 548-564. https://doi.org/10.1645/GE-715R.1 
Crompton D.W.T. 1985. Reproduction. In: Crompton D.W.T. \& Nickol B.B. (eds) Biology of the Acanthocephala: 213-263. Cambridge University Press, Cambridge.

Dezfuli B.S., Onestini S., Carcupino M. \& Mischiati C. 1998. The cement apparatus of larval and adult Pomphorhynchus laevis (Acanthocephala: Palaeacanthocephala). Parasitology 116: 437-447. https://doi.org/10.1017/S0031182098002492

Dezfuli B.S., Capuano S., Pironi F. \& Mischiati C. 1999. The origin and function of cement gland secretion in Pomphorhynchus laevis (Acanthocephala). Parasitology 119: 649-653.

https://doi.org/10.1017/S0031182099005193

Forssell A.L. 1904. Echinorhynchus semermis n. sp. Meddelanden af Societatis pro Fauna et Flora Fennica 13: 175-179.

Forssell A.L. 1905. [Contribution to the knowledge of echinorhynchs of fishes in Finland.] Acta Societatis pro Fauna et Flora Fennica 27: 1-29. [In Swedish.]

García-Varela M., Francisco J.A., Pérez-Ponce de León G., Piñero D. \& Laclette J.P. 2005. Molecular phylogeny of Corynosoma Lühe, 1904 (Acanthocephala), based on 5.8S and internal transcribed spacer sequences. Journal of Parasitology 91: 345-52. https://doi.org/10.1645/GE-3272

Helle E. \& Valtonen E.T. 1981. Comparison between spring and autumn infection by Corynosoma (Acanthocephala) in the ringed seal Pusa hispida in the Bothnian Bay of the Baltic Sea. Parasitology 82: 287-296. https://doi.org/10.1017/S0031182000057036

Hernández-Orts J.S., Timi J.T., Raga J.A., García-Varela M., Crespo E.A. Aznar F.J. 2012. Patterns of trunk spine growth in two congeneric species of Acanthocephalan: investment in attachment may differ between sexes and species. Parasitology 139: 945-5. https://doi.org/10.1017/S0031182012000078

Hernández-Orts J.S., Smales L.R., Pinacho-Pinacho C.D., García-Varela M. \& Presswell B. 2017. Novel morphological and molecular data for Corynosoma hannae Zdzitowiecki, 1984 (Acanthocephala: Polymorphidae) from teleosts, fish-eating birds and pinnipeds from New Zealand. Parasitology International 66: 905-916. https://doi.org/10.1016/j.parint.2016.10.007

Hewer H.R. 1964. The determination of age, sexual maturity, longevity and a life-table in the grey seal (Halichoerus grypus). Proceedings of the Zoological Society of London 142: 593-624.

https://doi.org/10.1111/j.1469-7998.1964.tb04631.x

Kaimoto T., Hirazawa T., Masubuchi T., Morohoshi A., Katahira H. \& Kobayashi M. 2018. Host characteristics and infection level of an intestinal parasite Corynosoma strumosum (Acanthocephala) in the Kuril harbour seals of Erimo Cape, Hokkaido, Japan. Parasitology International 67: 237-244. https://doi.org/10.1016/j.parint.2017.12.008

Leidenberger S. \& Bäcklin B.-M. 2008. [Species determination and distribution of parasites of grey seals (Halichoerus grypus) with intestinal ulcers in Sweden]. NRM Rapport 2008-12-18. [In Swedish.] World Wide Web electronic publication. Available from http://www.nrm.se/download/18.42d44b9511f368fc8af80005782/1367705036573/LeidenbergerB\% C3\%A4cklinParasiter2008.pdf [accessed Oct. 2018].

Leidenberger S. \& Boström S. 2008. Characterization of the heartworm Acanthocheilonema spirocauda (Leidy, 1858) Anderson, 1992 (Nematoda: Onchocercidae) in Scandinavia. Parasitology Research 104: 63-67. https://doi.org/10.1007/s00436-008-1159-1

Leidenberger S. \& Boström S. 2009. Description of the lungworm Otostrongylus circumlitus (Railliet, 1899) de Bruyn, 1933 (Metastrongyloidea: Crenosomatidae) found in the heart of seals from Sweden. Journal of Nematode Morphology and Systematics 12: 169-175. 
Leidenberger S., Hårding K. \& Härkönen T. 2007. Phocid seals, seal lice and heartworms: a terrestrial host-parasite system conveyed to the marine environment. Diseases of Aquatic Organisms 77: 235-253. https://doi.org/10.3354/dao01823

Lisitsyna O.I., Kudlai O., Spraker T.R., Tkach V.V., Smales L.R. \& Kuzmina T.A. 2019. Morphological and molecular evidence for synonymy of Corynosoma obtuscens Lincicome, 1943 with Corynosoma australe Johnston, 1937 (Acanthocephala: Polymorphidae). Systematic Parasitology 96: 95-110. https://doi.org/10.1007/s11230-018-9830-0

Lühe M. 1904. Geschichte und Ergebnisse der Echinorhynchen-Forschung bis auf Westrumb (1821). (Mit Bemerkungen über alte und neue Gattungen der Acanthocephalen). Zoologische Annalen, Zeitschrift für Geschichte der Zoologie 1: 139-354.

Lühe M. 1911. Acantocephalen. Register der Acanthocephalen und parasitischen Plattwürmer, geordnet nach ihren Wirten. In: Brauer (ed.) Die Süsswasserfauna Deutschlands. Eine Exkursionsfauna. Heft 16: 35-41. Gustav Fischer Verlag, Jena.

Montreuil P.L. 1958. Corynosoma magdaleni sp. nov. (Acanthocephala), a parasite of the gray seal in Eastern Canada. Canadian Journal of Zoology 36: 205-215. https://doi.org/10.1139/z58-021

Mutterer J. \& Zinck E. 2013. Quick-and-clean article figures with FigureJ. Journal of Microscopy 252: 89-91. https://doi.org/10.1111/jmi.12069

Nickol B.B., Helle E. \& Valtonen E.T. 2002. Coryonosoma magdaleni in gray seals from the Gulf of Bothnia, with emended descriptions of Corynosoma strumosom and Corynosoma magdaleni. Journal of Parasitology 88: 1222-1229.

https://doi.org/10.1645/0022-3395(2002)088[1222:CMIGSF]2.0.CO;2

Popov V.N. \& Fortunato M.E. 1987. [Geographic variation of Corynosoma strumosum (Acanthocephala, Polymorphidae) - a parasite of marine mammals.] Zoologicheskii zhurnal 66 (1): 12-18. [In Russian.] [Canadian Translation of Fisheries and Aquatic Science No. 5589. ISSN 0704-3726].

Rudolphi K.A. 1802. Fortsetzung der Beobachtungen über die Eingeweidewürmer. Archiv für Zoologie et Zootomie 2: 1-67.

Schindelin J., Arganda-Carreras I., Frise E., Kaynig V., Longair M., Pietzsch T., Preibisch S., Rueden C., Saalfeld S., Schmid B., Tinevez J.Y., White D.J., Hartenstein V., Eliceiri K., Tomancak P. \& Cardona A. 2012. Fiji - an Open Source platform for biological-image analysis. Nature Methods 9: 676-682. https://doi.org/10.1038/nmeth.2019

Schindelin J., Rueden C.T., Hiner M.C. \& Eliceiri K.W. 2015. The ImageJ ecosystem: an open platform for biomedical image analysis. Molecular Reproduction and Development 82: 518-529.

https://doi.org/10.1002/mrd.22489

Seinhorst J.W. 1959. A rapid method for the transfer of nematodes form fixative to anhydrous glycerine. Nematologica 4: 67-69. https://doi.org/10.1163/187529259X00381

Sinisalo T., Kunnasranta M. \& Valtonen E.T. 2003. Intestinal helminths of a landlocked ringed seal (Phoca hispida saimensis) population in eastern Finland. Parasitology Research 91: 40-45. https://doi.org/10.1007/s00436-003-0893-7

Sinisalo T., Poulin R., Högmander H., Juuti T. \& Valtonen E.T. 2004. The impact of sexual selection on Corynosoma magdaleni (Acanthocephala) infrapopulations in Saimaa ringed seals (Phoca hispida saimensis). Parasitology 128: 179-185. https://doi.org/10.1017/S003118200300430X

Steinauer M.L., Nickol B.B. \& Ortí G. 2007. Cryptic speciation and patterns of phenotypic variation of a highly variable acanthocephalan parasite. Molecular Ecology 16: 4097-4109.

https://doi.org/10.1111/j.1365-294X.2007.03462.x 
Väinölä R., Valtonen E.T. \& Gibson D.I. 1994. Molecular systematics in the acanthocephalan genus Echinorhynchus (senus lato) in northern Europe. Parasitology 108: 105-114.

https://doi.org/10.1017/S0031182000078574

Valtonen E.T., Helle E. \& Poulin R. 2004. Stability of Corynosoma populations with fluctuating population densities of the seal definitive host. Parasitology 129: 635-642.

https://doi.org/10.1017/S0031182004005839

Van Cleave H.J. 1945. The genital vestibule and its significance in the morphology and taxonomy of the Acanthocephala, with particular reference to the genus Corynosoma. Journal of Morphology 77: 299-315. https://doi.org/10.1002/jmor.1050770303

Van Cleave H.J. 1953. Acanthocephala of North American Mammals. Illinois Biological Monographs 23. The University of Illinois Press, Urbana.

Waindok P., Lehnert K., Siebert U., Pawliczka I. \& Strube C. 2018. Prevalence and molecular characterisation of Acanthocephala in pinnpedia of the North and Baltic Seas. International Journal of Parasitology: Parasites and Wildlife 7: 34-43. https://doi.org/10.1016/j.ijppaw.2018.01.002

Wayland M.T. 2010. Proboscis profiler: a tool for detecting acanthocephalan morphotypes. Systematic Parasitology 76: 159-167. https://doi.org/10.1007/s11230-010-9245-z

Manuscript received: 30 October 2018

Manuscript accepted: 15 February 2019

Published on: 10 April 2019

Topic editor: Rudy Jocque

Desk editor: Jeroen Venderickx

Printed versions of all papers are also deposited in the libraries of the institutes that are members of the EJT consortium: Muséum national d'Histoire naturelle, Paris, France; Meise Botanic Garden, Belgium; Royal Museum for Central Africa, Tervuren, Belgium; Royal Belgian Institute of Natural Sciences, Brussels, Belgium; Natural History Museum of Denmark, Copenhagen, Denmark; Naturalis Biodiversity Center, Leiden, the Netherlands; Museo Nacional de Ciencias Naturales-CSIC, Madrid, Spain; Real Jardín Botánico de Madrid CSIC, Spain; Zoological Research Museum Alexander Koenig, Bonn, Germany. 